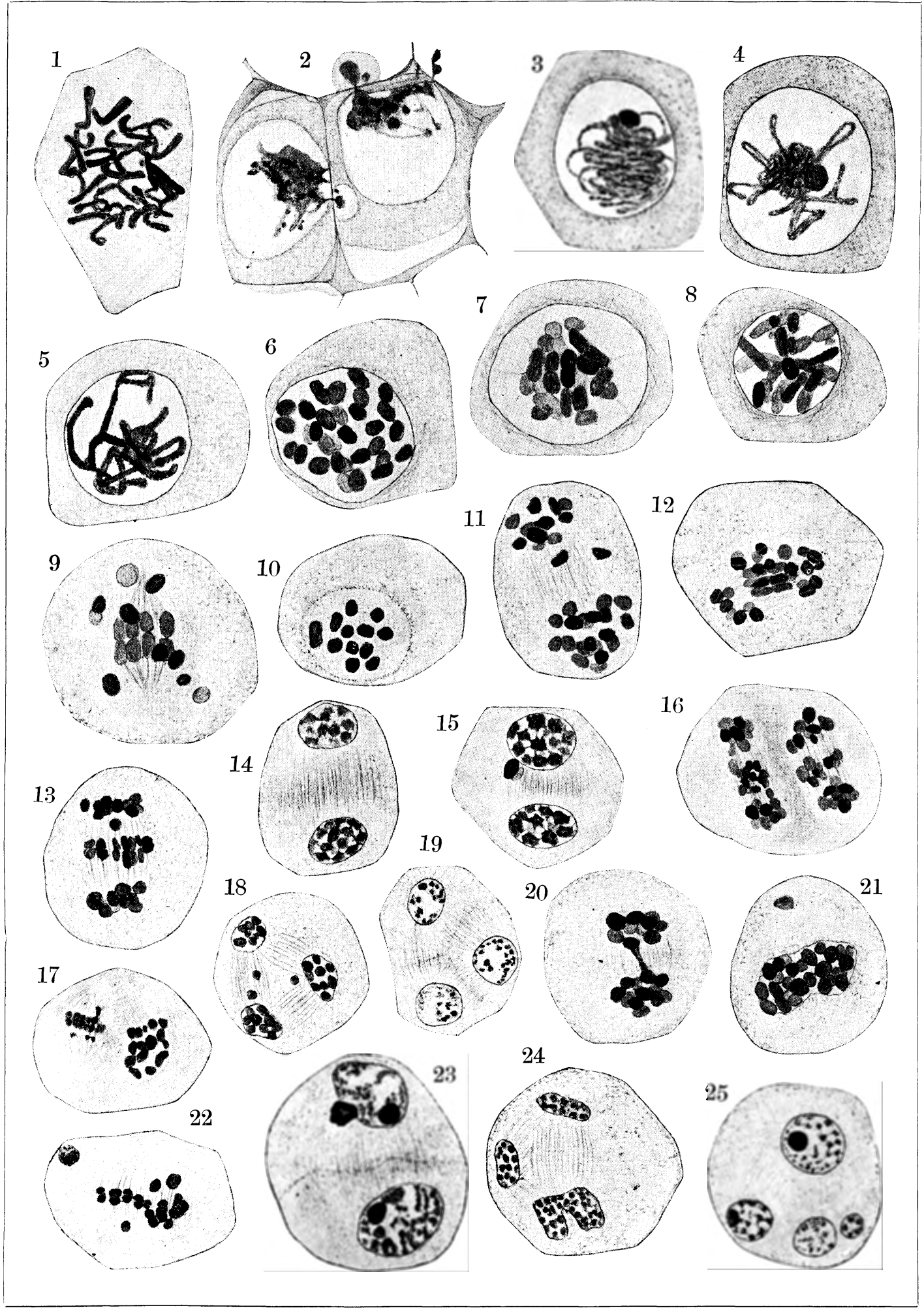




\section{On the Behavior of Chromosomes in the Meiotic Phase of Some Artificially Raised Papaver Hybrids.}

(Contributions to Cytology and Genetics from the Departments of Plant-Morphology and of Genetics, Botanical Institute, Science College, Tokyo Imperial University. No. 38.)

By

\section{Kono Yasui}

(With Plate III and one Text-figure)

Since Rosenberg's well known cytological studies on Drosera appeared in 1904, important contributions to the cytology of hybrid plants have been made by several authors, e. g., Gates $(1907,1909)$ and Geerts $(1909,1911)$ on Oenothera, Digby (1912) on Primula, Rosenberg (1917) on Hieracium, Kuwada (1919) on Zea, KiHara (1920, 1921) on Triticum; and the importance of the study in this direction is now rapidly increasing, especially with regard to the question of sterility of hybrid organisms and the origin of variations or new forms due to hybridization.

The present paper deals with some of the results of studies of certain Papaver hybrids, carried on since 1919, under the direction of Prof. FujII, with a view to some knowledge of the internal mechanism of genetics of hybrids.

\section{Materials and Methods}

The parent plants in this experiment were Papaver orientale L., $P$. somniferum L., and $P$. Rhoeas L.; but the present paper is limited to the account concerning the $\mathrm{F}_{1}$ Plants between $P$. orientale and $P$. somniferum.

The diagnosis given below are limited to the characteristics to be considered in the present experiment.

Papaver orientale L. Perennial herb. Stem and leaf stiff-hairy. Leaves deep green, hispid pinnately cut. Sepals 2 as a rule, 
sometimes 3. Petals 4-6, scarlet with a dark purple patch at the base of each petal. The patch greatly varies in size and the depth of colour. Stamen deep purple. Capsule glabrous, glaucous, with deep violet stigma.

In 1919 three individuals derived from the culture in the Botanic Garden of the College of Science, Tokyo Imperial University were used for the pollen parents. Flowers of these individuals were also selfed, and the seeds were sown in the autumn of the same year. Almost all $S_{1}$ plants flowered in 1921.

Papaver somniferum L. Annual herb. Plant glaucous, glabrous ; leaves broad, oblong, lobed and waved, with glaucous hue, broadly cordate at the base and clasp the stem. Sepals 2 ; corolla double or single; petal laciniate or entire, white or coloured. Anther pale yellowish with white filament. Stigma yellowish white.

In 1916 Professor FujII got some 10 different kinds of seeds of cultivated $P$. somniferum from the town Sukagawa, Fukushima Prefecture, through Mr. R. Endo, which were used as materials for genetical experiments. Since then through 3 or 4 generations, which were selfed or crossed, 20 or more races have been secured concerning the following characteristics of the flower:

Doubleness or singleness of corolla,

Laciniated or entire petals,

Presence or absence of red pigment in the petal,

Presence or absence of violet pigment in the petal,

Presence or absence of purple patch at the base of the petal.

$F_{1}$ plants in the present paper were raised from seeds got by. the crossings :

1. Papaver somniferum $\mathrm{L}$. (white double) $\times P$. orientale $\mathrm{L}$.

2. Papaver somniferum $\mathrm{L}$. (white single) $\times P$. orientale $\mathrm{L}$.

3. Papaver somniferum L. (red double, without purple patch at the base of petals $) \times P$. orientale $\mathrm{L}$.

Fixing and staining. Material for cytological studies were fixed with Flemming's stronger solution and Benda's solution, the latter being found preferable to the former. For the staining of sections were mostly used Heidendain's iron-alum-haematoxylin and FlemMING's triple staining method.

\section{External Characters of $F_{1}$ Plant}

According to Focke (1881), BRoussonet's record on the Papaver hybrids is the first one on Papaver hybrids. Focke des- 
cribed also about the hybrid plant between $P$. orientale and $P$. somniferum produced by GodRon in 1866, some of which lived until 1875, in the following manner:

" Pflanze hochwuchsig, Blüthen kaum kleiner als bei $P$. orientale, meist mit 6 Kronblättern. Pollen missgebildet, Kapseln völlg steril. Im Uebrigen die Charaktere gemischt. Godron beobachtete an mehreren Blüthen Fehren der Narbenpapillen, an zweien je 4 Kelchblätter, an einer beginnende Aufösung der Kapsel in einzelne Carpelle."

My $F_{1}$ plants agree in many respects with the above description but are characterized by the following points :

1. $F_{1}$ plants are generally perennial like $\sigma^{-1}$ parent, more vigorous than either of the parents, rhizome thicker, leaves more numerous in the rosette. Some individuals, died off after only one season like + parent. The hybrid plants which germinated in autumn, flowered in the next spring, while the offsprings of the parent mostly passed two winters before they flowered.

2. The shape of leaf is intermediate between those of the male and the female parents, and the stem and leaves are hispid like $\sigma^{\pi}$ parent, with somewhat waxy surface like the 우 parent.

3. The flowering shoot is generally unbranched like $o^{-1}$ parent; but in some individuals branched as in the of parent.

4. Petals were single scarlet, either 4 or 6 and sometimes 5 like $0^{\pi}$ parents, as in Focke's description. But there is one thing to emphasize, that is, notwithstanding the fact that the doubleness of the flower of Papaver somniferum is a dominant character over the singleness in the same species, in the hybrid $F_{1}$ plants it is found to be recessive to the singleness of $P$. orientale, so far as the material at hand has shown.

5. The dehissence of anther is always incomplete, and the pollen grains irregular in size, many of them being sterile.

6. There were found no such imcomplete capsules as FockE described about the GoDron's hybrids, but some individuals showed polycephaloidy.

\section{Cytology of $F_{1}$ Plant}

$F_{1}$ plants from the three kinds of crossings above mentioned showed generally all the same diagnosis; so they are mentioned hereafter in this paper without distinction. 
1. The chromosome number of the somatic nucleus. According to TAHARA (1915), the haploid number in $P$. orientale is 21 , and that in $P$. somniferum 11 which were confirmed in my own observations. The somatic or diploid number of chromosomes in my $F_{1}$ plant was found to be 32 (Pl. III, Fig. 1) just the sum of the haploid numbers in the $0^{*}$ and 8 parent plants.

2. The meiotic division of the pollen mother cell. The synaptic knot seems to consist of many small irregular masses. In the earlier spireme stage, no trace of the doubleness of the thread due to the longitudinal splitting or the parallel approach of two threads could be ascertained. When the segmentation of the thread is complete and the chromosomes are established, the latter is clearly found to be 32 in number (Pl. III, Fig. 6).

After the second contraction (PI. III, Fig. 7), 22 out of 32 chromosomes form 11 bivalent chromosomes, consequently there are 11 bivalent and 10 univalent chromosomes in the diakinesis (Pl. III, Fig. 8). Each bivalent chromosome consists of two equivalent chromosomes united end to end, not side by side.

When the nuclear membrane disappears, the bivalent chromosomes migrate toward the center of the nuclear mass, where they form the equatorial plate, and receive a part of spindle fibres (Pl. III, Fig. 10, 11). At that stage, all the chromosomes show longitudinal splits.

All the eleven halves of the bivalent chromosmes generally go together to the anaphase; but frequently seven of them are already in the anaphase, while the remaining four are found still in the metaphase (Pl. III, Fig. 12). After halves of each bivalent chromosomes left the equator for the opposite poles, the univalent chromosomes now taking the place of the latter, entering the equatorial region of the spindle, form a secondary equatorial plate (Pl. III, Fig. 13). In this position, they split longitudinally and their halves follow the preceding chromosomes for the opposite poles. Thus in the hybrid $F_{1}$ plant, all chromosomes do not always pass the metaphase simultaniously, but sometimes in two or even three successions.

The part played by the univalent chromosomes in the formation of the daughter nuclei is various: (1) Some of them situated too far from the center do not enter the spindle, the result being their exclusion from the nucleus, when the nuclear membrane is established; (2) univalent chromosomes, though entering the spindle at the equator and move toward the poles, break their step, so that while some of them are already in the telophase, others are left behind and thus 
excluded from the daughter nuclei; (3) some univalent chromosomes get into the spindle, not at the equator, but very near to the one pole; therefore notwithstanding their being split into two halves, the halves pass to one and the same pole, instead of being carried to the opposite poles; (4) in some material the split univalent chromosomes, left outside the daughter nuclei, serve a bridge connecting the daughter nuclei, (Pl. III, Fig. 20) the result is a dumbell shaped nucleus very much like the abnormal nuclei which were got by SAKAMURA in his interesting experimental study (1920). Some of these irregular large nuclei contract afterward and become rounded, so they do not show any difference compared with the normal nuclei, except the abnormally large size and the much larger number of chromosomes they contain.

After the first division of the pollen mother cell, the achromatic fibres of the spindle disappear gradually and many granules appear at the equatorial region of the mother cell, but no partition membrane is formed.

At the interkinesis, chromosomes become irregular in shape and size, and are connected each other with fine protrusions. No nucleolus appears in the latter stage (Pl. III, Fig. 14, 15). When the second division soon starts and chromosomes are established, the large chromosomes split longitudinally, but the small ones do not. The former may be interpreted as derived from the bivalent chromosomes, while the latter from the univalent ones. The divided chromosomes arrange themselves to form the equatorial plate first, and after they reached the anaphase, the undivided chromosomes come into the spiudle which is bipolar from the beginning (Pl. III, Fig. 16, 17). The axes of the two spindles are not in a definite relation, sometimes parallel, sometimes perpendicular, and sometimes inclined to each other. The second equatorial plate is always somewhat irregular. The distribution of the undivided chromosomes is not even, so that very often in the telophase many chromosomes are left in the cytoplasm (PI. III, Fig. 18). They may be single or in groups of two or more, and being surrounded by a membrane, partial or miniature nuclei (Pl. III, Fig. 25) are formed. So the pollen mother cell frequently contains one or more small nuclei in addition to the normal or larger nuclei. When pollen grains are formed in the mother cell, some of the miniature nuclei may get into a pollen grain, together with the normal nucleus (Text-fig. 1, c), but sometimes the miniature nucleus with accompanying cytoplasm may 
form a small pollen grain by itself, so that some pollen mother cells contain some extra pollen grain or grains.

Fig. 1.
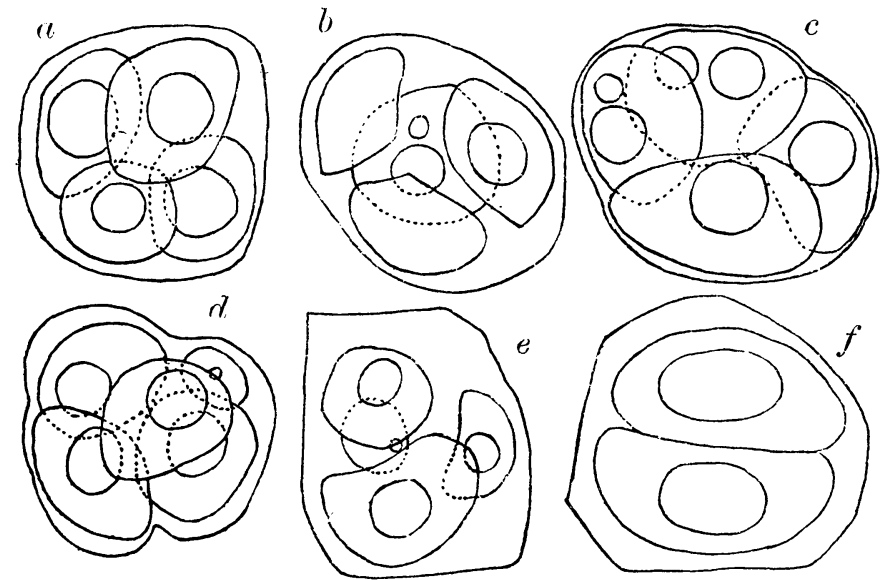

Fig. 1. The pollen mother cells, with young pollen grains formed in it. a, four pollen grains formed; $b$, a mother cell containing four pollen grains, one at center with an isolated chromosome besides a normal nucleus, one to the left and one below, containing no nuclei, under way of degeneration; c, two grains contain each an extra dwarf nucleus; $d$, a mother cell containing four normal sized pollen grains and a dwarf pollen grain; e, a mother cell containing one abnormally large pollen grain (diploid), two ordinary pollen grains and a $d$ warf pollen grain; $f$, a mother cell having two unusually large (diploid) pollen grains.

The division of the large nucleus, resulting from the fusion of the two daughter nuclei, formed by the first division, very much resembles an ordinary somatic division, and it results in the formation of two large daughter nuclei (Pl. III, Fig. 23), each of which has naturally an excessive number of chromosomes for a haploid nucleus. Thus the large pollen grains, only two in number contained in a mother cell, may be produced. (Text-fig. 1, f).

In some specimen, two daughter nuclei of the first division, having no partition wall between, are situated very near to each other; then the two spindles of the second division disturb each other, so that there arise great irregularities. Likewise the two groups of telophasic chromosomes derived from two different nuclei sometimes 
unite together at the approached poles of the two different spindles. while the opposite poles remain free. This results in the formation of the three nuclei in a pollen mother cell instead of four (Pl. III, Fig. 24). As the consequence an abnormal large diploid pollen grain and two normal pollen grains are produced in such a mother cell (Text-fig. 1. e).

From the various modes of development of pollen grains, which I have described here, we see that all the pollen grains formed in a pollen mother cell may differ from each other, not only quantitatively but also qualitatively.

At about the anaphase of the second division or earlier than that, there appear many vacuoles in the cytoplasm in some pollen mother cells, and degeneration of the nucleus and cytoplasm takes place, the result of which is the abortion or sterility of the pollen grains.

3.' Cytomixis.' As is shown in Pl. III, Fig. 2, the nuclear substances of a mother cell in prophase, may pass into the cytoplasm of the neighbouring pollen mother cell or cells, through the pits of the cell membrane. This phenomena were already observed by KoERnicke (in Crocus, 1901), Gregory (in Sweet pea, 1909), Gates (in Oenothera, 1911) Digby (in Primula, 1912) and others. Some of them ascribed this phenomenon to an artificial production, but others, e.g., Gates, as a natural process in the meiosis. I have seen the same phenomenon also in the preparations of the pollen mother cell in synapsis of Papaver orientale and in diakinesis of $P$. somniferum, so that it seems not seldom to find this phenomenon in the meiotic phase in fixed materials; but on account of the fact, that it does not always occur even in the same plant materials and in the same stage of cell division, I am inclined to the view that this phenomenon is to be taken for an artifact which is caused by the fixing liquid, when the protoplasm is in a state particular to the stage of mitosis.

\section{General Considerations}

1. Hybrid nature of the plant and the irregular behavior of chromosomes. In the prophase of the meiosis of the hybrid plants artificially raised between the parents, which have different numbers of chromosomes, the bivalent and univalent chromosomes are formed. The former pass the metaphase regularly, while the latter may or may not follow the same route. In either case, it is chiefly the behavior of these univalent chromosomes, which cause the irregular 
division of the pollen mother cell. The similar process was first observed by Rosenberg in Drosera hybrid (1904) and afterwards by Gates (Oenothera, 1907, 1909), GeERTs (Oenothera, 1909, 1911), Rosenberg (Hieracium, 1917) Kinara (Triticum, 1920, 1921) and others in artificially raised hybrids. Lately TÄсHOLM, and also BLACKBURN and HARrison studied several forms of roses independently, and the latter two authors highly emphasized the presence of univalent chromosomes in the prophase of the first division of meiosis as an indication of hybrid nature of the plant. My Papaver hybrid is an additional example of the presence of univalent chromosomes as well as the irregular behavior of chromosomes in the meiotic prophase in experimentally raised hybrids. But even the fact that hybrid plants show the irregular chromosome behavior is universal, yet the converse can not be always true, so that it does not necessarily follow that plant showing irregular chromosomes behavior is of hybrid origin.

2. End to end-union and parallel-union of chromosomes. There were two different types of the gemini formation described, the end to end-union and the parallel-union. Authors who have studied artificially raised hybrids, generally describe end to end-type. My material also shows the same. Though I am not yet prepared to give a definite account of comparison aboat the same stage of cell division in $\mathrm{my}$ hybrid Papaver and the parent plants, it may be suggested here that the end to end-union is the phenomenon which occurs when the affinity or similarity of geminal chromosomes is in a lower degree.

3. Behaxior of the univalent chromosomes. They undergo the longitudinal split either in the first or the second division. The case of Triticum figured by KIHARA is the one, which is typical to the former instance. The case of the Papaver hybrid is very much like his result; the univalent chromosomes on the spindle of the first division of meiosis split into two, and in majority of cases each halves of the univalent chromosomes follow the halves of the bivalent chromosomes for the opposite poles, but in the case of Papaver, there is more irregularity in the behavior of univalent chromosomes and sometimes it resembles the diagram $\mathrm{C}$ of the meiosis in the Pisosella of Rosenberg, in which some univalent chromosomes pass undivided to one of the opposite poles. In the second division of the meiosis, however, ordinary univalent chromosomes part themselves, not undergoing the longitudinal division for the second time, as is the case with Rosenberg's Hieracium, in unequal numbers for the opposite poles of the spindle. Consequently the distribution of 
heredity substances to the opposite poles is there unlike the usual homeotypic division as a rule, decidedly unequal in the second division. Once I met with the case belonging to the RosenbeERG's Drosera-type.

4. Behavior of chromosomes and the origin of variations. On account of the irregularity of the chromosomes distribution in the meiotic division of the pollen mother cell, the pollen grains of the $F_{1}$ plant between Papaver orientale and P. somniferum are different from each other in the heredity substances they contain. If even a part of these pollen grains were fertile, then the offsprings of $F_{1}$ plant will show proportions of the combination of the factors different from the Mendelian expectation, and the number of different kinds of offsprings will be richer than in the Mendelian expectation.

It is possible that such a process due to hybridization takes place sometimes in nature, and becomes a cause of the origin of variations.

The large pollen grains, whose cell nuclei were produced by the fusion of two nuclei in the meiotic division, are provided with diploid nuclei. Sperm cell from such pollen grains have the possibility of producing a triploid or tetraploid plant in mating with a haploid or diploid egg.

The above mentioned irregularities of the chromosome distribution will be a concrete case belonging to the fourth item of the causes of the origin of new forms or species postulated by FujI (1920)

5. Amitosis-like figures in the meiotic nuclei. The two nuclei in the process of fusion in the first or second meiotic division present the figure very much like that which has been often described as amitosis (Juel, Ticshler, Osawa eitc.). Sakamura (1920) observed the similar nuclei in the root cells and the pollen mother cells of Vicia faba treated with chloralhydrate and other agents, and he regarded them as the reconstruction figures of mitotic nuclei which were temporarily disturbed on the way of division, and not as the nuclei in the process of amitosis. I follow the latter author in regarding them not as amitosis. I take them for the fusion of nuelei, and it may be added here, that such a process may well occur in nature under several external and internal influences acted on the plasma in the meiotic phase.

6. Sterility of hybrids. As a cause of the sterility in hybrid plants, many authors, e. g., Juel (1900), Tischler (1908), Bateson (1907), and Gates $(1907,1909)$, pointed out the irregular behavior of the 
chromosomes in the meiotic phase, though some authors, e. g., TISCHLER emphasized the disturbance in metabolism.

We have to distinguish the two kinds of sterility of hybrid plants, i. e., the sterility of gamates and the nonviability or abortion of zygotes.

STERILITY OF GAMATES. The egg cell of $P$. somniferum is fertile, the pollen grain of $P$. orientale is normal, and the hybrids between these two species is viable and even vigorous than the parents; that is to say, protoplasm of the male cell of $P$. orientale does not affect the viability of that of the female cell of $P$. somniferum and vice versa; and the vegetative function of the zygote protoplasm is even promoted. Thus we are forced to the conclusion that the degeneration of the pollen grains of $F_{1}$ plant is due to the abnormal distribution of chromosomes, which actually take place in the meiotic division, and the consequent inadequate 'idic combination' (FujIr, 1920 ) of the nucleus of the pollen cells. Eleven halves of 'somniferum gemini' as well as 21-halves of 'orientale gemini' will form viable gamates; but only 11 out of 21 halves of the latter will be probably incomplete to form a viable gamate. It follows then that 11 halves of 'somniferum gemini' is not probably equivalent each to each with those $\mathbf{1 1}$ halves of 'orientale gemini'; and the interchange of chromosomes between these two sets to form a pollen cell nucleus in the process of meiosis will naturally produce inadequate or non-viable chromosome sets to form gametic nuclei and this tendency will be greater, the more of univalent chromosomes happen to be dropped off in the formation of the latter.

NONVIABILITY OF ZYGOTES. A small number of ripe seeds in the capsule, is probably due to a large number of nonviable unions from various kinds of gamates, and this is the main cause of the abortion of zygotes.

There is besides one thing to be considered, however, regarding the cause of the abortion of zygotes; that is the fact of sterility of $P$. orientale, the $o^{7}$ parent. In 1919 , seven flowers of $P$. orientale were selfed, but only one capsule produced ripe seeds. In 1921 about 30 flowers of the $S_{1}$ plants from the 1919 seeds were selfed, but no capsule formed ripe seeds. In face of the facts of the regularity of the meiotic process, which is nearly certain from the figures by TAHARA and of the normal development of good pollen grains, we can hardly suppose the sterility of the male gamates. Although I am not in a position yet to give any decisive account about the 
development of female gamates it seems to be probable that there is a lethal factor or factors for the development of the embryo. And the lethals of $P$. orientale might have been inherited and caused the sterility of $\mathrm{F}_{2}$ plant; i. e., not the lethals formed in the meiotic division of $F_{1}$ plant, but these inherited from the parent.

\section{Summary}

1. In the prophase of the meiotic division of the Papaver hybrid, chromosomes forming gemini, unite end to end, not side by side.

2. There appear 11 bivalent chromosomes and 10 univalent chromosomes in the first meiotic division. The bivalent chromosomes form the equatorial plate first; all the eleven chromosomes may pass to the anaphase simultaneously, or seven of them first and remaining four afterward; the univalent chromosomes may follow the same process after the halves of the bivalent chromosomes left the equator for the opposite poles of spindle. They make the longitudinal split at the equator and the halves move to the opposite poles.

3. The univalent chromosomes, which remained outside the spindle or did not get to the pole before the nuclear membrane appears, are left in the cytoplasm.

4. In the second divison of meiosis, the large chromosomes, probably derived from the bivalent chromosomes from the equatorial plate earlier than those from univalent chromosomes.

As in first division, some chromosomes derived from the univalent chromosomes are left in the cytoplasm. Some of them remains as isolated chromosomes in the cytoplasm, but some, single or two or more in groups are inclosed by themselves in separate membranes and thus form miniature nuclei.

5. As the result of the irregular behavior of the chromosomes, occasionarily two daughter nuclei of the first division of meiosis, connected by a bridge of isolated chromosomes, unite to form a single nucleus. The union of two nuclei, beloning to two different spindles of the second meiotic division, also takes place. The result in the appearance much resemble an amitotic division. Such nuclei form a kind of diploid pollen grains.

6. The irregular behavior of chromosomes in the meiotic division, the union of two nuclei, and dropping of certain chromosome cause the abnormalities of pollen grains, not only in shape and size, but also in the combinations of the heredity substances. 
This may contribute to the origin of the variation or new forms in the offsprings on the one hand, while this may affect the viability of the male gamates and cause the sterility on the other hand.

7. $F_{1}$ plants between Papaver somniferum and $P$. orientale are more vigorous than their parent plants. The $F_{1}$ plant appears mostly like $P$. orientale the $\sigma^{t}$ parent, but in some external characters it is intermediate between both parents. The male gamates are mostly sterile.

In closing I wish to express $\mathrm{my}$ cordial thanks to Professor $\mathrm{K}$. FujII for the valuable materials given me for this experimental study and important advices and criticisms throughout the course of the work. My deep thanks are also due to Professor J. Matsumura and Dr. T. NAKaI for the facilities given during the progress of the experiment.

\section{Literature Cited}

BAteson, W. (1907) The progress of genetics since the rediscorery of Mendel's papers. Prog. rei Bot. 1, p. 368 .

Blackburn, K. B. and Harrison, J. W. H. (1921) The status of the British rose form as determined by their cytological behavior. Ann. Bot. vol. 35, p. 159.

Davis, B. M. (1911) Cyto!ogical studies on Oenothera III. Ann. Bot. vol. 25, p. 941.

DigBy, L. (1912) Cytology of Primula hybrids. Ann. Bot. vol. 26, p. 357.

Farmer, B. (1912) Telosynapsis and parasynapsis. Ann. Bot. vol. 52, p. 623.

Focke, W. O. (1881) Die Pflanzen-mischlinge.

FuJII, K. (1920) On the conception of "Id" and the question of its transmutability, (Japanese). Bot. Mag. Tokyo. vol. 34, pp. (99)-(125).

Gates, R. R. (1907) Pollen development in hybrids of Oenothera lata $\times$ Oe. Lamarckana and its relation to mutation. Bot. Gaz. vol. 43, p. 81 .

(1909) The behavior of chromosomes in Oenothera lata $\times$ Oe. gigas. Bot. Gaz. vol. 48 , p. 179 .

Geents, J. M. (1999) Beiträge zur Kenntniss der Cytologie und der partiellen Sterilitat von Oenothera Lamarckiana. Recueil. Trav. Bot. Neerl. v. livr. 2-4, pp. 93-209.

(1911) Cytologische Untersuchungen einiger Bastarde von Oenothera gigas. Ber. deut. bot. Gesellsch. Bd. 29, S. 160.

Jues, H. O. (1900) Beiträge zur Kenntniss der Tetradentheilungen. Jahrb. wiss. Bot. Bd. 35, S. 627 .

Kinara, H. (1920) Über cytologische Studien bei einigen Getreide-arten. Mitteilung I. But. Mag. Tokyo. vol. 32, p. 17.

- (1921) Über cytologische Studien bei einigen Getreide-arten. Mittellung III. Bot. Mag. Tokyo. vol. 35, p. 17.

KuwadA, Y. (1919) Die Chromosomenzahl von Zea Mays L. Journ. Coll. of Sci. Tokyo Imp. Univ. vol. 39, Art 10. 
Lutz, A. M. (1909) Notes on the first generation hybrid of Oenothera lata 우 $\times$ Oe. gigas, o Science N. S. vol. 29, p. 263.

Osawa, J. (1913) Studies on the cytology of some species of Taraxacum. Arch. Zellforsch. Bd. 10, S. 450.

Rosenberg, O. (1904) Über die Tetradenbildung eines Drosera Bastardes. Ber. deut. bot. Gesellsch. Bd. 22 S. 47.

(1917) Die Reduktionteilung und ihre Degeneration in Hieracium. Svensk Bot. Tidskr. Bd. 2, S. 145

Sakamura, T. (1920) Experimentelle Studien über die Zell und Kernteilung mit besonderer Rucksicht' auf Form, Grösse und Zahl der Chromosomem. Journ. Coll. of Sci, Tokyo Imp. Univ. vol. 29, Art 11.

Tahara, M. (1915) The chromosomes of Papaver (Japanese). Bot. Mag. Tokyo. vol. 29, p. 254.

T̈̈скногм, G. (1920) On the cytology of the genus Rosa. A preliminary note. Svensk Bot. Tidskr. Bd. 14, S. 300.

TIschler, G. (1903) Über eine merkwurdige Wachsthumserscheinung in den Samenanlagen von Cytisus Adami. Ber. deut. bot Gesellsch. Bd. 21, S. 82.

- (1906) Über die Entwicklung der Sexualorgane bei einem sterilen Brionia Bastarde. Ber. deut. bot. Gesellsch. Bd. 24, S. 383.

- (1907) Weitere Untersuchungen über Sterilitätsursachen bei Bastardpflanzen. Ber. deut. bot. Gesellsch. Bd. 25, S. 376 .

(1908) Zellstudien an sterilen Bastardpflanzen. Arch. Zellforsch. Bd. 1. S. 35.

\section{Explanation of Plate III}

All figures were drawn with the aid of a camera lucida, and with a Zeiss' apochromatic objective $2 \mathrm{~mm}$ and a comps. ocular $12(\times 15)$. Afterward all the figures. were reduced $9 / 10$.

Fig. 1. A somatic cell showing 32 chromosomes.

Fig. 2. A pollen mother cell in synapsis stage, showing the extrusions of the nuclear substance.

Fig. 3. A pollen mother cell in synapsis stage.

Fig. 4. Early spirem stage.

Fig. 5. Later spirem stage.

Fig. 6. Still later stage, when 32 chromosonies are formed.

Fig. 7. Second contraction.

Fig. 8. Diakinesis. The bivalent and univalent chromosomes are seef.

Fig. 9. The metaphase of the bivalent chromosomes. The univalent chromosomes are scattering in the cytoplasm.

Fig. 10. The polar view of equatorial plate of the bivalent chromosomes, one longer isolated chromosome is a univalent chromosome.

Fig. 11. Later anaphase of the first division, showing both daughter chromosome grours having different chromosome numbers.

Fig. 12. Seven bivalent chromosomes are in later anaphase, but remaining four are in metaphase, and the univalent chromosomes are approaching to the equator.

Fig. 13. The equatorial plate of the univalent chromosomes.

Fig. 14. Interkinesis, normal. 
Fig. 15. Interkinesis, showing a chromosome left in the cytoplasm.

Fig. 16. Second division of meiosis.

Fig. 17. The same, but axes of two division spindles are perpendicular to each other.

Fig. 18. A tetrad, some chromosomes are left in cytoplasm.

Fig. 19. The partition wall formation between four pollen nuclei, one is not shown in this figure.

Fig. 20. Two chromosome groups connected by the chromosome bridge.

Fig. 21. Chromosomes in the beginning of the second division of the fused nucleus.

Fig. 22. Metophase of the division of the fused nucleus.

Fig. 23. Later stage of the latter, the partition wall being formed.

Fig. 24. The fused two nuclei at the telophase of second division.

Fig. 25. A pollen mother cell containing one large, two normal sized, and one dwarf nuclei. 